\title{
The Role of Social Business in Environmental Protection through Poverty Alleviation
}

\author{
Md. Wahidul Alam', Mohammad Hassan Shakil', Md. Kazi Golam Azam³, \\ Mashiyat Tasnia ${ }^{4}$
}

${ }^{1}$ Department of Business Administration, International Islamic University Chittagong, BANGLADESH ${ }^{2}$ Graduate Studies Department, INCEIF-The Global University of Islamic Finance, Kuala Lumpur, MALAYSIA

${ }^{3}$ Assistant Professor, Department of Business Administration, International Islamic University Chittagong, BANGLADESH

${ }^{4}$ Professional Studies Department, INCEIF-The Global University of Islamic Finance, Kuala Lumpur, MALAYSIA

\begin{abstract}
Social Business runs for the welfare of people rather to profit maximization. In the economic system of Bangladesh there are mainly two types of organization models. Companies of private sector sell products or services to make profit while non-profit organizations are financed by the government. When both the governments and private sector reach their limits, charity organizations fill up the deficiency. Nowadays, we have forgotten to involve the poor into the economy. And exactly that target group is full of potential but has never had a real opportunity. Only such opportunities can be provided to them through social business. The study is of analytical and theoretical in nature and based on secondary data. It encompasses the fact that success of social business sector in Bangladesh is noteworthy as Bangladesh is taking various successful steps to go ahead in poverty alleviation and environmental protection through new alternative arrangement named Social Business. The paper depicts that Social Businesses of Bangladesh is trying to contribute in environmental protection through poverty alleviation by its different extensive programs. Various new integrated model and new Social Business idea will support in this regard. The Social Business can easily overcome the impediments in environmental protection and poverty alleviation by implementing policy formulated in this study.
\end{abstract}

Keywords: Poverty, Social Business, Environmental Protection and Poverty Alleviation 


\section{INTRODUCTION}

\section{Poverty}

Poverty is a complex societal issue. It is a great enemy to human happiness. It certainly destroys liberty, and it makes some virtues impracticable, and others extremely difficult. Poverty is defined as general scarcity or dearth, or the state of one who lacks a certain amount of material possessions or money. So it is the deprivation of well being. However, poverty is more, much more than just not having enough money. The World Bank Organization describes poverty in this way:

"Poverty is hunger. Poverty is lack of shelter. Poverty is being sick and not being able to see a doctor. Poverty is not having access to school and not knowing how to read. Poverty is not having a job, is fear for the future, living one day at a time."

\section{Social Business}

In social business, the investor gets his/her investment money back over time, but never receives dividend beyond that amount. So, social business is a non-dividend company which is cause-driven rather than profit-driven with the potential to act as an agent of change, dedicated entirely to achieve social goals. The main purpose of the business is to solve a predetermined social problem in a sustainable way. It can co-exist with conventional business. It also differs from classical market models because its primary objective is social utility and the creation of social value is inseparable from the objective of financial viability. It follows the "no loss, no dividend" principle and is based on a structure capable of producing a product or service that can satisfy a community's basic needs. It can be treated as Community Need Business (CNB) or Social Need Business (SNB).

\section{Environment}

Environment is the sum total of all surroundings of a living organism, including natural forces and other living things, which provide conditions for development and growth as well as of danger and damage. For a country's overall economic development, we have to essentially analyze the country's environmental attributes i.e. the characteristics of a program or project (such as particulate emissions, thermal discharge, waste discharge) that determine the type and extent of its short-term and long-term impacts on its environment. A country's physical, cultural, demographic, economic, political, regulatory, or technological environment also affect the survival, operations, and growth of an organization. Bangladesh's steady economic growth has created many environmental challenges, particularly in urban and industrialized areas. The Country Environmental Analysis for Bangladesh underpins complex linkages between poverty, growth and environmental management.

\section{OBjectives OF THe Study}

The main objective of the study is to evaluate the role of social business in poverty alleviation and environmental protection.

To attain the core objective the following specific objectives are considered:

- To analyze the significance of social business in fighting poverty

- To examine the social business plan for protecting environment through reducing poverty

- $\quad$ To suggest some policy implications. 


\section{Methodology OF THE Study}

The study is of analytical and theoretical in nature and based on secondary data. Data sources are collected from various newspapers, magazines, websites, articles and other publications by different leading institutions. Other research papers related to the title are also taken into consideration. Collected data were then analyzed and sorted to enrich the literature of the study. Microsoft office package has been used for summarizing and illustrating the collected data systematically.

\section{LITERATURE REVIEW}

"Many parts of the world are caught in a vicious downwards spiral: Poor people are forced to overuse environmental resources to survive from day to day, and their impoverishment of their environment further impoverishes them, making their survival ever more difficult and uncertain" (WCED, 1987: 27). The focus on the poverty-environmental linkage has emerged from two different camps. Those concerned with poverty studies have increasingly realized the importance of the state of the environment in determining the magnitude of poverty. More than other groups, the poor depend on the income derived from the use of the natural resource base. In spite of this fact, "if there has been a single thread running through forty years of investigation into the poverty of poor countries, it has been the neglect of this resource base" (Dasgupta and Mäler 1995: 2373).

The orthodox model of environment and poverty suggests that rural poverty increases the forces behind degradation of resources. This was argued to be a key part of the explanation behind crisis models of environmental pressure such as the Himalayan theory of deforestation and soil erosion, the fuelwood crisis; desertification, and the negative impacts of shifting cultivation (Eckholm, 1976; Kasperson et al,1996; Brown et al, 1998). 'Social Business' was first formally developed by Nobel Laureate Professor Muhammad Yunus in 2010 through a book titled Building Social Business with a view to creating a poverty-free world (Latifee, Enamul Hafiz, 2013). Micro-credits have been praised as one of the most powerful instruments for poverty reduction at a local level, earning Muhammad Yunus from Bangladesh and his Grameen Bank the Nobel Peace Prize in 2006. But while a growing number of critics or skeptics such as BANERJEE et al. (2009), BATEMAN (2010), or COLLINS et al. (2010) are questioning their reach, use, and effectiveness, development experts actively call for multidimensional poverty reduction strategies in response to the phenomenon's social, economic, political, and environmental causes and effects (Scholz 2004; Nuscheler 2008; Rauch 2009).

There are lots of micro-finance organizations (NGO's) in Bangladesh who are trying to develop poor as well as vulnerable people providing microloans with or without requiring any collateral or mortgage. But in various studies it has been proved that micro-loans are not always able to alleviate poverty (Matin, Sulaiman and Rabbani, 2008).

A total of 42,101 women have been engaged in woodlot, agro-forestry, and strip plantations, which is almost $30 \%$ of total participants engaged in the program. Again, Rahman et.al. (2010) have examined the agro-forestry project (a component of SF project) mainly in social point of view. They focused on broader aspects of this project. They found average annual income in Betagi and Pomra to be equal to BDT 53,200 and BDT 34,280 respectively for each family. In the project area farmer's literacy rate has increased due to involvement with SF project. 
Many of the studies found that "to date there has not been adequate exploration of financial products and low-cost service delivery mechanisms that would allow MFIs to serve extremely poor households without compromising sustainability objectives" (Hickson, (1999), SEEP Poverty Outreach Working Group, (2006)). Particularly, the ultrapoor, who are somehow too poor to work, require extensive rehabilitation to mutate them into productive resources. Productivity itself can often be the catalyst of rehabilitation (Sorenson \& Sachi, 2011).

\section{THE SIGNIFICANT ROLE OF SOCIAL BUSINESS TO ALLEVIATE POVERTY}

Over the years, three clear facts have emerged:

- Social problems cannot be solved by governments alone;

- $\quad$ Big companies are having negative impacts on society (WBCSD, 2007);

- Society has expectations of big companies (Hart, 2007).

In response, whether to regulatory requirements or to important internal commitments, major companies have for several years been developing various types of CSR approaches (Martinet et Payaud, 2009).

According to Yunus (Page xii- xiv, Building Social Business), we can create a poverty-free world if we redesign our system to take out its gross faults which create poverty. He compared poor people with 'bonsai' tree and remarked that if we could help poor people out of poverty by creating an enabling environment, then it is a matter of time only to resolve worldwide poverty problem. But the question arises how this redesign process can be integrated into the traditional way of economic thinking and doing business to help out these 'bonsai' people. Well, it cannot be rejected that humans are selfish beings, but they are simultaneously selfless - the worldwide existing institutions are not only designed to generate maximum individual wealth but also to establish mosques, churches, synagogues, art museums, public parks or health clinics or community centers which are the strong illustrations of selflessness motive of human beings as these institutions don't make anyone a tycoon.

So, if the flaw of economic theory based on one dimensional person is recognized and replaced with one based on multidimensional person (a person who has both selfish and selfless interests at the same time), then the problem would be solved (Page xvi, Building Social Business). So, a new kind of business known as social business should be selfsustaining, that is, it generates enough income to cover its own costs and part of the economic surplus is invested in expanding the business, while a part is kept in reserve to cover uncertainties. Moreover, in this kind of business, the company makes a profit, but no one takes the profit (Page xvii, Building Social Business). So, this is the way how social business actually gets started in traditional business.

Initially, Grameen Bank allowed the poor to be an actor in the free market and to enjoy some of its fruits to try to come out of poverty. It is fundamentally a business model, pure and simple, but a social business. There can be other social businesses. They are just like any other business; but for social objectives and not for personal gain or dividend. Social business should not be confused with the term social enterprise which is used in a more encompassing sense and includes NGOs, personal initiatives, charities, etc., and may include social business too. While Bangladesh's success in social development has widely been emulated in many parts of the world -- reflected in Grameen and BRAC's global expansion -- the country stands to benefit in many ways banking on the ideas that are emanating from its social sector. Muhammad Yunus' vision of social business, for instance, 
that has its origin in microcredit, is increasingly attracting global attention. One of the basic principles of social business is that investors and owners can gradually recoup the money invested, but cannot take any dividend beyond that point.

Academics and universities around the world see social business as a niche area to conduct research. Some leading universities have already instituted research centers to institutionalize the idea. Social media (facebook, twitter etc) is quick to spread the concept from Dhaka to Durban. Nevertheless, the idea of social business is no more limited to thinking. Several companies based on these ideas have been launched in Bangladesh to eradicate poverty. Some leading global brands such as Danone, BASF, Adidas and Uniqlo, among others, have been working with Grameen to develop some essential products such as yogurt, mosquito nets, shoes and clothes at an affordable price.

Bangladesh draws minuscule amount of foreign direct investment (FDI) due to, among other factors, the institutional drawbacks and political risks. This costs the country in many ways. FDI flow bridge finance gap, generate employment and narrow the technology gap, inter alia. The interest generated by social business can be an important channel to narrow all these gaps to a large extent. Moreover, the potential innovation in various projects is likely to generate huge positive externalities, greatly benefiting the society. Social business zones can also be instituted to support the multinational companies (MNCs) and local entrepreneurs. While the emerging economies are spending billions of dollars and offering various incentives to host the multinational companies (MNCs), the virtues of social business are prompting them to set up units in Bangladesh. The government is not required to spend a single penny. If the dozens of joint venture initiatives that Garmeen has undertaken are proven to be financially and socially sustainable businesses then hundreds of social entrepreneurs can come forward emulating the model.

The "Social Business" concept developed by Nobel Peace Prize Laureate Prof. Muhammad Yunus has the purpose to achieve a maximum of social benefit through the production of affordable but high-quality products and services adapted to the low purchasing power of poor people. A company operating as a "Social Business" needs to work profitably in order to cover emerging costs and to invest its earnings in the expansion of the business. In this way, their products become accessible for the poor. Cooperation of the Grameen Group with international companies such as BASF or Danone show that the model can work and that it also helps international companies to adapt their business strategies to the needs of markets with low purchasing power.

The following diagram present how the social business is contributing towards the alleviation of poverty: 


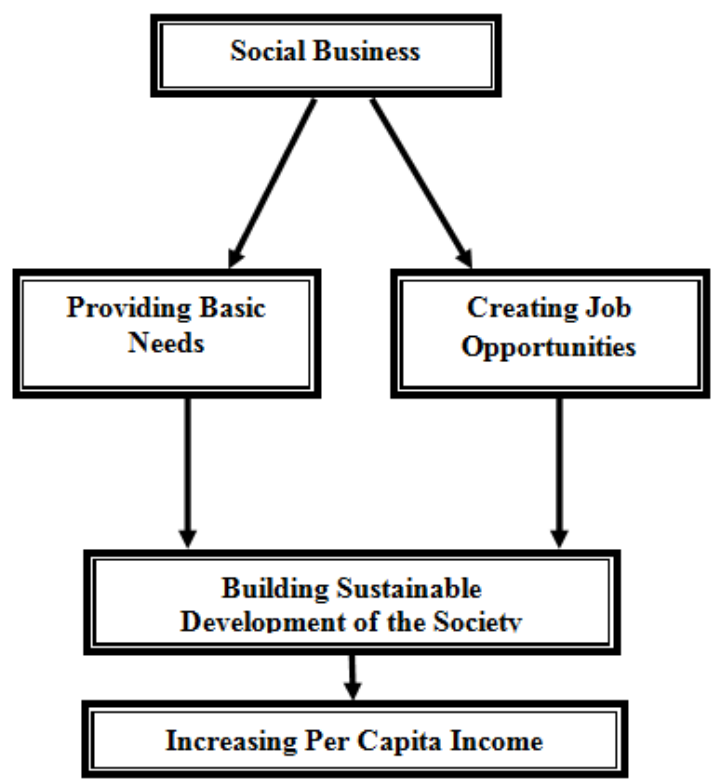

Figure 2: How Social Business alleviates poverty

The above illustrated diagram is about the way how the social businesses are conducting their business operation. According to the diagram social businesses are conducting their operation by focusing on two sides. In one side they are addressing the basic needs of the society's people and in another side they are trying to create job opportunities for the poor people. From the very beginning to till today's date and also in future social business will follow the above operational model for their business operation to address the poverty into museum.

\section{Poverty AlLeViation LeaVes Impact on EnVIRONMENT}

At the beginning, when the social business concept induced the core objective was to give the best alternative arrangement to alleviate poverty as traditional business system alone cannot bring the expected change in this sector. The world is changing - and so are companies. Because when society's needs change, business must adapt including social business. Before, the increasing number of social enterprises - big and small - from around the Bangladesh is addressing poverty, resource scarcity and social inequality in a proactive manner. But now-a-days, comparing with the current situation social business's entrepreneur has to consider the environmental issue along with poverty alleviation. Therefore, the approaches to such issues require rethinking. As the overloaded phrase "sustainable development" of the society must recognize the interconnectedness between human beings and the environment if true environmental and social justice is to be obtained. Environmental degradation and poverty alleviation are urgent global issues that have a lot in common so Bangladesh cannot escape from this vital issue. From Bangladeshi perspective, the widespread nature of social and environmental ills leads us to consider the social business model from a new dimension. Through the poverty alleviation program taken by different social enterprises environmental issue also can be addressed in a perfect manner. In short, the goods and services created by a social business need to be designed to provide benefits to poor people or to serve society in other ways-for example, by improving health care, cleaning the environment, enhancing environmental knowledge, reducing the vulnerability to natural disasters. 
The following will provide an analytical overview about how poverty alleviation leaves impact on environment:

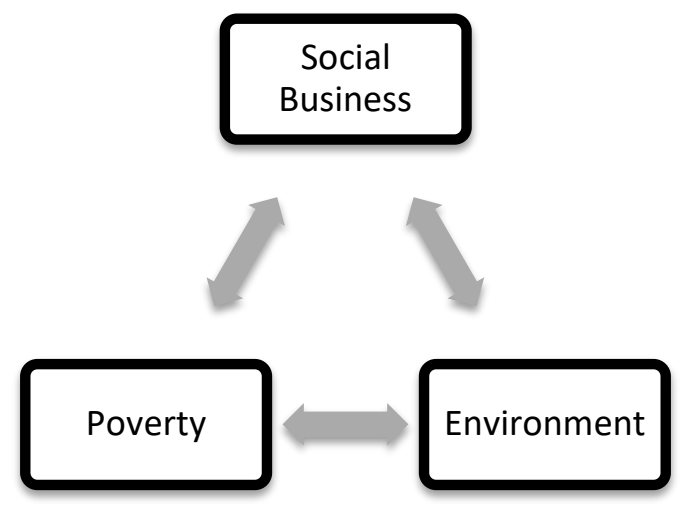

Figure 9: poverty alleviation leaves impact on environment

Issues about environment and poverty are inter-related through the way humans interact with their surroundings and with each other. The relationship between human activity and the natural environment are complex. So when Social Business concerned about alleviating poverty they also leaves impact on environment.

\section{HOW POVERTY LEADS TO DEGRADATION OF ENVIRONMENT}

Poverty is considered as a great influence of environmental degradation. People everywhere consume water, food, energy and other natural resources in order to live. All economic activity is based on resources from nature. Any productive activity can deplete natural resources and cause environmental stress. Delhi-based environment organization, the Centre for Science and Environment, points out, if the poor world were to develop and consume in the same manner as the West to achieve the same living standards, "we would need two additional planet Earths to produce resources and absorb wastes and good planets are hard to find!"

Bangladesh has suffered from various environmental problems such as increasingly devastating floods, often believed to be resulting from large-scale deforestation. Forests around the world face increased pressures from timber companies, agricultural businesses, and local populations that use forest resources. For years, rich countries are started to establish polluting industries to poor countries like Bangladesh, but still producing primarily for rich countries. This has been possible in so far as it is cheaper than to pay for costly environmentally clean technologies that people demand. In many regions of our country, regional overgrazing has resulted in destruction of grazing lands, forest and soil. Air and water have been degraded. The carrying capacity of the natural environment has been reduced. As the people become poorer, they destroy the resources faster. They tend to overuse the natural resources because they don't have anything to eat or any means of getting money except through the natural resources, they start to depend more on natural resources.

Poor people harvest natural resources for their survival or in order to meet their basic needs such as firewood, agricultural productions (such as maize), and water and wild plants for their medicine. All people regardless of being poor or rich depend on natural resources; the concern with poor people is that they are utilizing the resources directly. The rich people do depend on these resource but they do not go to the forest directly and harvest the resources. They have no quality drinking water as they pollute the rivers by washing inside them and by also using a river as a dumping site for the bins. The lack of education also prohibits them 
from practicing environmentally sustainable agriculture; protect natural resources against degradation or rehabilitate degraded resources like rivers.

\section{Environmental Degradation InTO EnVIRONMENTAL Benefit}

Over the last decade the poverty-environment hypothesis has become a major concern of international development agencies and policy makers. Environmental degradation and poverty reinforce each other: the poor are both agents and victims of environmental destruction. In such case the remedy comes to our society in the name of social business to turn the environmental degradation into environmental benefit through eradicating the poverty situation in our country as much as possible. Some of these ways are discussed below:

\section{Increasing Biodiversity}

Poverty reduction helps in developing the Industrial Agriculture by increasing biodiversity, requiring green farming system which reduces the excessive use of pesticides \& fertilizers, the destruction of diverse source of foods, the use of fossil fuels, water \& toxic chemicals in the process. Thus when biodiversity increases it also maintains a balance between different species while producing foods since cattle and earthworms are our partners in food production, stealing food from them makes it impossible to maintain food production over time. Besides sufficient access to education and to information make it easier for poor people to manage available natural resources in a sustainable and sound manner, thus creating the livelihood opportunities and biological diversity; nowadays which are mostly contributed by the social business organizations besides the government roles regarding poverty elimination.

\section{Reducing excessive burden on Natural Resources}

Natural resources are not only life sustaining (clean air, clean water, fertile soils, trees which turn carbon dioxide into oxygen, etc) but also they constitute the basic economic assets of hundreds of millions of people. Soil degradation through erosion, overuse or use of chemical products, overgrazing, or Stalinization resulting from inadequate water management entail loss of income base for small farmers and doom them to poverty. In our previous chapter, we see how different types of social business organizations are working in our country to alleviate poverty by making the productive use of these resources \& thus generating the employment which ultimately leads the poor to make a low pressure on the use of natural resources, such as, fisheries, livestock etc. Thus the proper use of resources maintain an ecological balance in the environment which also leads the poor neighborhoods' to adequate waste collection and waste management with subsequent solution to health problems \& proper use of energy resources leads to reducing waste and higher energy costs that end up being unaffordable for the poor.

\section{Making the Environment Free of Pollution}

When people put much pressure on the nature it hazardously creates pollution, such as, air pollution, water pollution, soil pollution etc. Air, water and soil pollution create health hazards in addition to damaging economic assets. In this case when social business companies help the poor engage in other effective forces for their employment rather than the natural forces, in consequence, it helps the environment get free of different kinds of pollution. For Example:

- Air pollution can be removed by generating appropriate production techniques where poor people will be involved \& by investing capital in environment friendly technologies. 
- In the similar way water pollution which can also be removed by providing sufficient access to information on proper management - eradication of the soils sterilizing, improving fisheries, solving health problems, and takes a lower toll on the poor.

- Again such effective steps help the poor people in rural areas who confine to marginal lands contribute to the de-acceleration of erosion, decreased ecological vulnerability, landslides, etc.

\section{Forestation}

Poverty reduction leads to forestation through appropriate use of wood and other resources for cooking, heating, housing and crafts, thus helping the vulnerable groups from essential goods and de-accelerating both the downwards spiral of poverty and environmental degradation. For example:

- Bangladesh has suffered from various environmental problems such as increasingly devastating floods, often believed to be resulting from large-scale deforestation. So when people engage in different industrial sector for their better earning \& livelihood as a result they don't rely on the forest resources for their livelihood which in turn leads to the forestation.

- Besides the forests around the country face increased pressures from timber companies, agricultural businesses, and local populations that use forest resources. So when people will stop cutting down the trees destructively \& plant more \& more trees, it will also be helpful for these companies as well as our natural environment.

\section{POLICY IMPLICATION}

The study finds many pertinent and urgent policies for implication towards the role of social business in environmental protection through poverty alleviation:

\section{Proper Government Policy}

There is no better thought \& well established government policies to facilitate the social business \& thus encourage the social entrepreneurs around the country. Here it is essentially suggested that thoughtful government policies are required to bolster the social business sector's possibility of success in achieving marked social \& environmental change regarding the poverty elimination.

\section{Access to Basic Skill}

Access to finance is now less of a problem for many social enterprises than access to basic skills. Often, social entrepreneurs lack basic skills in accounting, bookkeeping and business planning, meaning they may lack credibility with lenders or donors. Lack of English language skills can also be a barrier to social entrepreneurs seeking to engage with donors or multinational companies. So, Social entrepreneurs need training in basic business skills along with in new technologies and financing mechanisms.

\section{Including in the National Curriculum}

Now-a-days the topic social business can be found into some special book written by the person involved with this sector. So, common people are not enough aware about this sector as they do not possess the eagerness to study those special book. Social business should be included as an individual course in the national curriculum of Bangladesh. Moreover higher courses need to be introduced on the social business in different public \& private Universities. By doing so, the message and concept of social business can be conveyed among the common people through the students. 


\section{More campaign and training program}

The current social business programs can not perceived the expected result in broad scale as campaigning and training programs are fall short than required. Moreover public awareness is required must for the expansion of their programs from locality to locality. To serve the purpose necessary steps need to be taken by the concerned authority to arrange more and more campaign and training program.

\section{Strategic support to local institutions}

Policymakers need to identify and then prioritize support to Social Enterprises (SE) which supports positive trajectories of livelihood change for particular groups of people, or paths of environmental change with positive implications for poor people's wellbeing.

\section{Establishment of research institute}

For generating new, innovative and full proof social business idea that can serve the purpose from the both side that is alleviating poverty and environmental protection research is must. Now-a-days research on social business is done in a limited scale. That cannot ensure the desired level of success. Moreover the outcome of a research cannot prove wrong as it is tested one. After considering the importance of research in social business sector a separate research institute needs to be set up with necessary arrangement. The researchers also need to provide with necessary incentive to remain absorbed in research.

\section{Expanding the Area of Business}

From the study about different social business companies, it is noticeable that their scope of business operation confines only to some particular areas. Social entrepreneurs should be more self-motivated \& foresighted to expand their scope of business operation especially in rural areas.

\section{Access to technical knowledge}

There are many opportunities for social entrepreneurs to use new technology, particularly in the field of clean energy, to promote sustainable economic development. Additionally a number of innovative financing mechanisms are emerging, often based on carbon credits, to fund such opportunities. It is found that the majority of social entrepreneurs, and the majority of people who are likely to engage with think tanks and donors, came from a public policy or economics background and were keener on solving economic or political problems than on using technology and innovative financing mechanisms.

\section{Promotion of Rural Employment}

It is one of the effective ways of eradicating poverty from a large scale area which can be promoted by social business in the following way:

- Generating more and better jobs through sustainable growth in rural areas.

- Delivering skills development in rural areas through agricultural and rural extension services, technical and vocational training programmes and communitybased training methodologies.

- Promoting employment through infrastructure and investment programmes, including labour-based approaches; employment guarantee programmes; and financial services like microcredit and micro leasing.

- Targeting programmes aimed at employment creation, including entrepreneurship, for youth and women in rural areas. 


\section{Green \& Social Business}

Being a green business is very important in today's world. Business owners have an increasing responsibility to be environmentally friendly and reduce their business' carbon footprint. With green business ideas and information on organic wholesalers and green gadgets, learn how one can not only start an eco-friendly business but also how to improve the green credentials of an existing business. Social enterprises often also have an environmental focus, or have other social or ethical business goals at their core. Below, there is information on setting up a social enterprise including legal issues, funding, ethical business practices and examples of existing social enterprises as well as expert advice on how one can become a social entrepreneur.

\section{Increasing Opportunities of Women Participation in economy}

Any serious attempt to address poverty by social business must be based on a sound analysis of the different situations of men and women especially in terms of power over resources. In the past two decades, Bangladesh has experienced significant poverty reduction and profound social transformation with the widespread entry of girls into the education system and women into the labor force. The country is on track to meet Millennium Development Goals for infant and child mortality and has already met the Millennium Development Goal for attaining gender parity in education. So the opportunities of women participation in the economy should be increased by-

- Increasing her access to employment opportunities in all spheres of economic activities through which she can earn a living, satisfy her basic needs for existence;

- Improving women's management and agricultural production capacities in the informal sector;

- Developing entrepreneurial skills so as to increase their initiatives to start up IGAs on their own;

- Having access to training, to technical skills, to factors and means of production and to marketing skills.

- Exploring the ways and means of introducing irrigated agriculture so that rural poor women can engage themselves in agricultural microenterprises as well.

\section{Environmental governance}

Governance is about decision-making - who makes the decisions, why, and how those decisions are implemented. It happens at all scales, from local community organizations through national governments to global institutions. Rigid governance is required to ensure the appropriate level of implementation of the formulated strategy by the social business entrepreneur for the sector of environment.

\section{How these Policy wiLl Benefit the Poor}

It is expected that the policy of the present study will be of benefit to the poor, especially for women in the following ways:

- Use of the policy by policy makers in lending institutions, NGOs and government might help them to draw some lessons in order to serve the poor better.

- Dissemination of policy to the poor might enable them learn from the experiences of others in alleviating poverty. 


\section{CONCLUSION}

Social Business can describe as a combination of community-based approaches and companies' lucrative innovations. Even though a company has to understand and know much about new and complex social and anthropological situations, it is not supposed to be an NGO but definitely to act as a genuine company. Companies have then to address these innovative issues and react with an entrepreneurial approach where social business can emerge. These are new forms of organization, combining social institutions and innovative companies seeking to provide solutions to the problems of poverty by developing inclusive approaches which ultimately leads to the environmental benefits. Considering the immense need of poverty alleviation and the perspective in which poverty exists, it can be said that winning the war against poverty in Bangladesh requires innovative efforts like promoting the idea of social business model and proper implementation of them. By creating value, innovation and opportunism and providing novel and successful ways; social business can alleviate poverty by addressing certain solutions to the environmental problems.

\section{REFERENCES}

Ahmed, Reaz (2010) "Jute genome decoded", The Daily Star.

Angelsen, Arild 1995. "Shifting Cultivation and 'Deforestation': A Study from Indonesia". World Development 23 (10): 1713-1729.

Angelsen, Arild 1997. "The Poverty-Environment Thesis: Was Brundtland Wrong?" Forum for Development Studies no. 1: 135-154.

Angelsen, Arild 1999 (forthcoming). "Agricultural Expansion and Deforestation. Modelling the Impact of Population, Market Forces and Property Rights". Journal of Development Economics, 55 (1).

Argos, M. et al. 2010. Arsenic exposure from drinking water, and all-cause and chronic-disease mortalities in Bangladesh (HEALS): a prospective cohort study. The Lancet 376, No. 9737(7):252258. DOI : 10.1016/S0140-6736(10)60481-3

Baland, Jean-Marie, and Jean-Philippe Platteau 1996. Halting Degradation of Natural Resources: Is there a Role for Local Communities. Oxford: Oxford University Press (for FAO).

Berry, Sara 1989. "Social Institutions and Access to Resources." Africa 59 (1): 41 - 55.

Blanchet, T. 2011. Grameen Veolia Water Ltd: Assessment of a Social Business project with an anthropologist perspective.

Budinich, V. Ashoka. 2005. "A Framework for Developing Market-Based Strategies that Benefit Lowincome Communities."

Cleaver, Kevin M., and Götz A. Schreiber 1984. Reversing the Spiral: The Population, Agriculture and Environment Nexus in Sub-Saharan Africa. Washington, D.C.: World Bank.

Colchester, Markus 1994. "Sustaining the Forests: The Community-based Approach in South and South-East Asia." In Development and Environment: Sustaining People and Nature, edited by D. Ghai. Oxford and Cambridge, MA: Blackwell Publishers (for UNRISD). Also Published in Development and Change, 25, 1994.

Dasgupta, Partha, and Karl-Göran Mäler 1995. "Poverty, Institutions, and the Environmental Resource Base." In Handbook of Development Economics, vol. III, edited by J. B. a. T. N. Srinivasan. Amsterdam: Elsevier.

Frerot, A. 2011. Intervention lors de la conférence "Du micro-crédit au Social Business: réalités ou utopies pour le rôle social des entreprises ?"

Ghimire, Krishna B. 1994. "Parks and People: Livelihood Issues in National Parks Management in Thailand and Madagascar." In Development and Environment: Sustaining People and Nature, edited by D. Ghai. Oxford and Cambridge, MA: Blackwell Publishers (for UNRISD). Also Published in Development and Change, 25, 1994. 
Hart, S. L. 2008. The Base of the Pyramid Protocol: Toward Next Generation BoP Strategy. Wharton School Publishing.

Hart, S. L. 2010 and 2007. Capitalism at the Crossroads: Next Generation Business Strategies for a PostCrisis World. FT Press.

Humberg, Kerstin Maria(2011), “Poverty Reduction through Social Business?” ISBN-13: 978-3-86581-287-2.

IDEO, 2009. Human Centered Design Toolkit 2nd Version. www.IDEO.com.

Kates, R., and V. Haarmann 1992. "Where the Poor Live: Are the Assumptions Correct?" Environment 34: 4-28.

Lawrence Summers, Let them eat pollution, The Economist, February 8, 1992. Quoted from Vandana Shiva, Stolen Harvest, (South End Press, 2000) p.65; See also Richard Robbins, Global Problems and the Culture of Capitalism (Allyn and Bacon, 1999), pp. 233-236 for a detailed look at this.

Leach, Melissa, and Robin Mearns 1992. Poverty and Environment in Developing Countries: An Overview Study. Sussex: Institute of Development Studies (IDS), University of Sussex.

Lele, Sharachchandra M. 1991. “Sustainable Development: A Critical Review." World Development 19 (6): 607-621.

Lesueur, E. 2011. Entreprises et Social Business : des solutions concrètes pour le développement. Lecture at the Conseil économique social et environnemental, Paris.

London, et al. 2009. Creating mutual value: Lessons learned from ventures serving base of the pyramid producers. Journal of Business Research In Press, Corrected Proof. DOI : 10.1016/j.jbusres.2009.04.025

London, T. and S. L Hart. 2004. Reinventing strategies for emerging markets: beyond the transnational model. Journal of International Business Studies 35, No. 5: 350-370. DOI : 10.1057 / palgrave.jibs.8400099

Lopez, Ramon 1992. "Environmental Degradation and Economic Openness in LDCs: The Poverty Linkage." American Journal of Agricultural Economics 74 (5): 1138-43.

Max-Neef, M. 1991. Human scale development. Conception, application and further reflections.

Nidumolu, R., C. K. Prahalad, and M. R. Rangaswami. 2009. Why sustainability is now the key driver of innovation. Harvard Business Review 87, No. 9: 57-64.DOI : 10.1109/EMR.2013.6601104

Nyer, Boston Edward(2011), "The Use of Biomass in High Efficiency Tobacco Curing for Small Holder Farmers in Bangladesh."

Perron ,J-L. 2011. Promoting and developing Social Business: A French Perspective [typo dans la VF]. The Journal of Social Business 1, No.1

Prahalad, C.K. 2005. The Fortune at the Bottom of the Pyramid: Eradicating Poverty Through Profits. Wharton School Publishing.

Reardon, Thomas, and Stephen A. Vosti 1995. “Links between Rural Poverty and the Environment in Developing Countries: Asset Categories and Investment Poverty." World Development 23 (9): 1495-1506.

Sen, A. 1981. Poverty and Famines: An Essay on Entitlement and Deprivation. Oxford: Clarion Press.

Shaw, R. Paul 1992. "The Impact of Population Growth on Environment: The Debate Heats Up." Environmental Impact Assessment Review 12: 11-36.

Sibieude, T. 2011. Co-creation with local communities for water access in rural Bangladesh: Research Workshop "Sustainability \& Impact challenges at the Base of the Pyramid."

Sibieude, T., Vidal, R. Cesselin, M. Riom, F. 2011. Le Protocole BoP 2.0. Traduction Française de "The Base of the Pyramid Protocol: Toward Next Generation BoP Strategy" (Hart, Simanis, 2008). 
Simanis, E. 2010. Next Generation Business Strategies for the Base of the Pyramid: New Approaches for Building Mutual Value > Strategic Opportunities > Needs, Needs Everywhere, But Not a BoP Market to Tap - Pg. 103

Simanis, E. 2010. The Anatomy of Market Creation: Insights from The Base Of The Pyramid. Cornell University

'Social business' fights poverty and malnutrition in Bangladesh, Jul 09, 2009, Source : BBC.

UNFPA (1991) Population and environment: the challenges ahead, New York: United Nations Population Fund

United Nations Development Programme (UNDP) 1998. Human Development Report 1998. New York: Oxford University Press.

United Nations Environment Programme (UNEP) 1995. Poverty and the Environment: Reconciling Short-term Needs with Long-term Sustainability Goals. Nairobi: UNEP.

UNPCSD (1995) Sustainable development and international economic cooperation: international cooperation for the eradication of poverty in developing countries, Report: A/50/393, 6 September 1995, New York: United Nations Department for Policy Coordination and Sustainable Development

UNPCSD (1997) Overall progress achieved since the United Nations Conference on Environment and Development: report of the secretary general: addendum - combating poverty,Report:E/CN.17/1997/2/Add.2, 17 January 1997, New York: United Nations Department for Policy Coordination and Sustainable Development.

UNSO (United Nations Sudano-Sahelian Office) (1994) Poverty alleviation and land degradation in the drylands: issues and action areas for the international convention on desertification, Paper produced in collaboration with R. Hay, P. Steele (EFTEC), and O. Noman of the Food Studies Group, Queen Elizabeth Hous, University of Oxford, Oxford.

Vandana Shiva, Stolen Social Business and big business: innovative, promising solutions to overcome poverty? », Field Actions Science Reports [Online], Special Issue 4 | 2012, Online since 06 March 2012, connection on 30 April 2014.Harvest, (South End Press, 2000), pp. 12-13.

Veolia Eau. 2009. Expertise et engagement développement durable de Veolia Water AMI.pdf.

Vidal, R. 2011. "Can a (safe)water market creation at the "Base of the Pyramid" solve the arsenic contamination problem in a Bangladesh village? The case of the Social Business Project Grameen Veolia Water Ltd", E. Ostrom master class, CIRAD, Agropolis, Montpellier.

Vidal, R. 2011. Knowledge and evaluation for transition towards sustainability. Research Workshop "Sustainability \& Impact challenges at the Base of the Pyramid."

WCED (World Commission on Environment and Development) (1987) Our common future: the report of the World Commission on Environment and Development, Oxford: Oxford University Press

Wilkinson, R. (1998) “What health tells us about society", IDS Bulletin 29:1 77-84

World Bank (1995a) Social dimensions of adjustment: World Bank experience, 1980-1993, Washington D.C.: World Bank

World Bank (1995b) "The ecoregional factor: new perspectives on malnutrition and poverty?" Human Capital Development and Operations Policy, No.55, August 281995

World Bank (1998) Poverty reduction and the World Bank: progress in Fiscal 1996 and 1997,Washington D.C.: World Bank 